\title{
SPECIFIČNOSTI ATRIBUIRANJA OSOBA SA PARANOIDNIM POREMEĆAJEM U ODNOSU NA DEPRESIVNE PACIJENTE I NEKLINIČKU KONTROLU
}

\author{
Nataša Cvejić-Starčević' i Zdenka Novović \\ Odsek za psihologiju, Filozofski fakultet u Novom Sadu
}

Poređenjem grupa depresivnih, paranoidnih i ispitanika bez poremećaja proveravane su pretpostavke o karakteristikama paranoidnog atribucionog stila. Pacijenti sa depresivnim $(N=58) i$ paranoidnim poremećajima $(N=30)$ poređeni su sa kontrolnom grupom ispitanika $(N=30)$ ujednačenih po starosti sa pacijentima. Primenjen je instrument zasnovan na Upitniku atribucionih stilova (ASQ) kojim su ispitivane dimenzije atribuiranja. Podaci su obrađeni multivarijatnom analizom kovarijanse, tako što su grupe činile nezavisnu varijablu, atribucione dimenzije zavisne, a važnost situacija koje su atribuirane, kovarijat. Rezultati su pokazali da paranoidni pacijenti više internalizuju uzroke uspeha, a eksternalizuju uzroke negativnih situacija, i imaju globalnije atribucije od ostalih grupa. Važnost situacija se pokazala značajnim činiocem atribuiranja, koji je u nekim situacijama $i$ značajniji od psihopatološkog poremećaja. Negativne situacije postignuća paranoidni pacijenti u većoj meri pristrasno atribuiraju, dok u negativnim socijalnim situacijama sve tri grupe teže pristrasnom atribuiranju, što ukazuje na važnost kontrolisanja tipa situacija $u$ istraživanju atribuiranja. Najvažnija implikacija rada je ukazivanje na značaj koji razvoj samopoštovanja ima u radu sa paranoidnim pacijentima, jer bi se na taj način menjala osnova za pristrasno atribuiranje.

Ključne reči: atribucije, paranoidni poremećaji, depresija, kognitivne pristrasnosti

\footnotetext{
${ }^{1}$ E-mail:yoda@eunet.yu
} 


\section{Uvod}

Prema Bentalovoj atribucionoj teoriji (Bentall, 1994), procesi atribuiranja (određivanja uzroka opaženih događaja) su specifični kod različitih psihopatoloških poremećaja. Specifičnost atribucionog stila je potvrđena mnogim istraživanjima (Bentall, Corcoran, Hoeard, Blackwood \& Kinderman, 2001; Blackwood, Howard, Bentall \& Murray, 2001; Beck \& Rector, 2002; Humphreys \& Barrowclouqh, 2006) na osnovu kojih se može pretpostaviti razlika u atribuiranju kod depresivnih, kod paranoidnih pacijenata i kod osoba bez poremećaja.

Atribucioni stil je konstrukt potekao iz novijih reformulacija Selidžmenove Teorije naučene bespomoćnosti, kao modela depresije (Seligman, 1975). Atribuciona revizija modela iz 1978, uvodi proces atribuiranja kao bitnu kognitivnu varijablu koja učestvuje u stvaranju naučene bespomoćnosti i depresije, kod osoba izloženih stresu (nekontrolabilnoj situaciji) (Abramson, Seligman \& Teasdale, 1978). U poslednjoj reformulaciji atribucioni stil se pojavljuje kao crta vulnerabilnosti koja povećava verovatnoću razvoja beznadežnosti i depresije (Alloy \& Clements, 1998). Atribucioni stil je dakle trajna tendencija osobe da interpretira situacije na određen, dosledan način (Seligman, 1990). Atribucioni stil podrazumeva da uzroci koje neka osoba pripisuje događaju zauzimaju relativno trajno mesto na sledećim atribucionim dimenzijama:

- Dimenzija internalnosti tiče se pretpostavke osobe o tome da li je uzrok događaja u njoj ili u drugim ljudima ili okolnostima: na jednom polu ove dimenzije, polu "internalnost", osoba uzrok koji pripisuje događaju vidi u potpunosti u sebi, dok ga na polu "eksternalnost" u potpunosti vidi u drugim ljudima ili okolnostima.

- Dimenzija stabilnosti odnosi se na pretpostavku osobe o trajnosti javljanja uzroka koji pripisuje događaju: "stabilni" pol ove dimenzije označava pretpostavku da će se taj uzrok stalno i kontinuirano javljati, dok njen "promenljivi" pol označava pretpostavku ili uverenje osobe da je taj uzrok trenutan i da više neće biti prisutan.

- Dimenzija globalnosti odnosi se na prepostavku odnosno uverenje osobe o generalnosti uticaja pripisanog uzroka na njen život: na "opštem" polu ove dimenzije je pretpostavka da taj uzrok utiče na sve situacije u njenom životu, dok je na "specifičnom" polu procena da taj uzrok utiče samo da neku konkretnu, posebnu situaciju (Mineka, Pury \& Luten, 1995).

Atribuciona teorija obezbeđuje okvir za razumevanje kauzalnih objašnjenja koje osoba daje za svoje i za ponašanje drugih ljudi (Fiske \& Taylor, 1991). Procenjeno je da normalne osobe verbalizuju kauzalne atribucije (tvrdnje koje uključuju ili impliciraju reči "zato što") na svakih nekoliko stotina reči (Blackwood et 
al., 2001). Normalni ispitanici dosledno ispoljavaju samopotvrđujuće atribuciono iskrivljenje pri objašnjavanju uzroka događaja: teže da sebi pripišu zasluge za uspeh (internalna atribucija za pozitivne događaje - "samoosnažujuća" distorzija) i da poreknu odgovornost za neuspeh (spoljašnja atribucija za negativne događaje - "samozaštićujuća" distorzija). Ova iskrivljenja mogu služiti uvećavanju samopoštovanja.

Najbrojnija istraživanja atribucionog stila tiču se atribuiranja depresivnih osoba i pacijenata, kod kojih je ustanovljena pristrasnost $u$ atribuiranju. Depresivni pacijenti su skloni da na samoporažavajući način interpretiraju događaje - sebe smatraju krivcima za negativne događaje koji im se dešavaju, a skloni su i da im pridaju veći značaj, da uzroke i posledice ovih događaja doživljavaju kao nepromenljive i delotvorne u velikom broju situacija (Abela, Brozina \& Seligman, 2004). Kada su u pitanju pozitivni događaji, depresivne osobe umanjuju sopstveni značaj u njihovom kreiranju, negirajući svoju odgovornost za njih i smatrajući ih posledicom prolaznih i specifičnih faktora (Sweeney, Anderson \& Bailey, 1986).

Bentalova Atribuciona teorija sumanutosti (Bentall, 1994; Bentall et al., 2001) je nastala na osnovu istraživanja kognitivnih procesa osoba sa sumanutostima. Nalazi istraživanja su ukazivali na specifičnosti tih procesa, pa su se dalja istraživanja proširila i na potvrđivanje njihove diskriminativnosti za različite psihopatološke poremećaje.

Specifičnost kognitivnih procesa za određene psihopatološke poremećaje ispitivana je mnogim istraživanjima koja je sproveo Bental sa saradnicima. U jednom od njih (Bentall \& Kaney, 1996), poređeni su paranoidni i depresivni pacijenti i normalni ispitanici prema pokazateljima magijskog mišljenja, lokusa kontrole i atribucionog stila. Istraživanje je pokazalo da paranoidni i depresivni pacijenti imaju više globalnih i stabilnih atribucija za negativne događaje, od normalnih ispitanika. Paranoidni pacijenti su u odnosu na druge dve grupe imali značajno više eksternalnih atribucija za negativne događaje i internalnih za pozitivne događaje. Zapažena je značajna i visoka razlika kod odgovora na subskali "moćnih drugih" upitnika o lokusu kontrole, i kod pokazatelja magijskog mišljenja između grupe paranoidnih ispitanika i druge dve grupe. Dimenzije „kontrolabilnosti” i "internalnosti" su bile varijable koje su takođe diferencirale grupe.

U ispitivanjima na kliničkim grupama su se tipično koristili upitnici u kojima se od ispitanika traži da izvedu zaključke o verovatnim uzrocima hipotetičkih pozitivnih i negativnih događaja. Pacijenti sa proganjajućim sumanutostima ispoljili su preterano samopotvrđujuće atribuciono iskrivljenje. Ekscesivno su pripisivali internalne uzroke hipotetičkim pozitivnim događajima (Kaney \& Bentall, 1989; 
Candido \& Romney, 1990), a spoljašnje uzroke hipotetičkim negativnim događajima (okolnostima ili drugim ljudima) (Kaney \& Bentall, 1989; Sharp, Fear \& Healy, 1997). Pacijenti sa sumanutostima neproganjajućeg sadržaja se nisu razlikovali od normalnih ispitanika po svom atribucionom stilu (Sharp et al., 1997), što ukazuje da atrubuciono iskrivljenje kod paranoidnih osoba oblikuje sumanuti sadržaj, a ne formu. Paranoidni pacijenti se izdvajaju i po tome što negativne događaje koji ih se lično tiču pripisuju aktivnoj zlonamernosti druge osobe (spoljašnja personalna atribucija) pre nego okolnostima ili slučaju (spoljašnja situaciona atribucija) (Kinderman \& Bentall, 1997).

Bental (Bentall, 1994) je predložio da ovo preuveličano atribuciono iskrivljenje služi održavanju samopoštovanja, ograničavajući svesnost o negativnim aspektima selfa smeštenih u semantičkoj memoriji. U skladu sa tim, kada se takve negativne predstave o sebi pobude opažanjem ugrožavajućih događaja, spoljašnje personalne atribucije (okrivljavanje drugih) se izvlače da spreče neusaglašenost između predstave o "aktualnom selfu" i predstave o "idealnom selfu". Aktiviranje ovih neusaglašenosti dovelo bi do gubitka samopoštovanja. Ovo atribuciono iskrivljenje kod paranoidnih pacijenata doprinosi negativnom opažanju namera drugih.

Zapravo, podaci o odnosu između samopoštovanja i paranoidne ideacije su izuzetno neusaglašeni: dok neki nalazi ukazuju na visoko samopoštovanje (Lyon, Kaney \& Bentall, 1994), drugi ga potvrđuju samo pri odsustvu depresije (Candido \& Romney, 1990), treći ukazuju na nisko samopoštovanje (Freeman et al., 1998), a neki nalazi pokazuju nepostojanje ikakve povezanosti.

Jedno moguće objašnjenje ovakve neusklađenosti nalaza istraživanja je varijabilnost odnosno nestabilnost samopoštovanja tokom vremena kod paranoidnih pacijenata (Bentall et al., 2001). Međutim, Čadvik i Trouer (Chadwick, Trower, Juusti-Butler \& Maguire, 2005) ukazali su na mogućnost postojanja dva tipa paranoje: "jadan sam" - nezaslužene paranoje i "loš sam" - kažnjavajuće paranoje. Ovaj prvi tip paranoje može biti povezan sa procesom atribuiranja gde se negativni događaji pripisuju spoljašnjem uzroku radi odbrane od samooptuživanja i niskog samopoštovanja, kao što predlažu Bental i saradnici (Bentall et al., 2001), dok drugi tip, u kojem je proganjanje zaslužena posledica toga što je pacijent "loš" može biti povezan sa mnogim depresivnim karakteristikama, uključujući i nisko samopoštovanje.

Pregled nalaza velikog broja istraživanja (Garety \& Freeman, 1999) može se svesti na zaključak o postojanju uverljivih dokaza o spoljašnjem personalnom atribucionom iskrivljenju za negativne događaje kod osoba sa sumanutostima 
proganjanja, dok hipoteza o "sumanutostima proganjanja kao odbrani" nije toliko pouzdano podržana dokazima.

Potvrda teze o specifičnosti atribucionog stila za različite psihopatološke poremećaje i preciznije definisanje tog stila kod pojedinih poremećaja i njihovih podtipova zahtevaju niz dodatnih istraživanja na uzorcima koji bi obuhvatali više psihijatrijskih kategorija, uz korišćenje testova koji nisu primereni istraživanju nekog konstrukta samo kod jednog poremećaja (Blackwood et al., 2001).

Cilj ovog istraživanja je potvrđivanje specifičnog atribucionog stila kod osoba sa paranoidnim poremećajima, koji ih diskriminiše od osoba sa depresivnim poremećajima, i od osoba bez poremećaja, kao i ispitivanje odnosa između atribucionog stila, vrste psihopatološkog poremećaja, pojedinih dimenzija atribucionog stila, i tipa situacije na koju se atribuiranje odnosi.

Konkretno, istraživanjem proveravamo Bentalovu hipotezu da je atribucioni stil paranoidnih pacijenata u pogledu atribuiranja pozitivnih situacija sličan atribuiranju opšte populacije, tj. pokazuje izraženo „samoosnažujuće atribuciono iskrivljenje“. Druga pretpostavka koja se testira je da paranoidni pacijenti slično depresivnim pacijentima imaju više stabilne i globalne atribucije za negativne događaje od normalnih. Kad su u pitanju negativni događaji, paranoidni pacijenti bi trebalo da ih interpretiraju u većoj meri spoljašnjim atribucijama, odnosno trebalo bi da poriču odgovornost za neuspeh - da ispoljavaju "samozaštićujuću" distorziju.

Ovim hipotezama koje su proizašle iz Bentalove teorije i nalaza nekih empirijskih istraživanja do sada, dodali smo još hipotezu da važnost situacija koje se atribuiraju može menjati odnos između poremećaja i atribuiranja, odnosno, da je procenu situacija na skali važnosti nužno držati pod kontrolom jer bi se različita važnost situacija koje su u testu date kao predstavnici četiri tipa situacija, mogla odraziti na atribuiranje. Takođe, pretpostavili smo da vrsta situacije (situacije povezane sa postignućem ili socijalne situacije) može biti od značaja u specifikovanju atribucionog stila paranoidnih pacijenata u odnosu na depresivne i kontrolnu grupu. Konkretno, pretpostavljamo da bi spoljašnje atribucije mogle biti u većoj meri zastupljene u negativnim socijalnim situacijama, budući da se socijalne situacije lakše mogu objasniti personalnim uzrocima (za neuspeh u komunikaciji sa drugima, najlakše je okriviti druge). 


\section{Metod}

\section{Uzorak}

Istraživanje je sprovedeno na 118 ispitanika od kojih je 30 ispitanka bez psihopatoloških poremećaja činilo kontrolnu grupu, i 88 pacijenata koji su hospitalizovani ili ambulantno lečeni zbog simptoma koji pripadaju nekom od depresivnih $(\mathrm{N}=58)$, ili paranoidnih poremećaja $(\mathrm{N}=30)$.

Grupa depresivnih bolesnika obuhvata pacijente koji se bolnički leče zbog poremećaja koji prema ICD-10 klasifikaciji mentalnih poremećaja (SZO, 1992) zadovoljavaju kriterijume za poremećaje iz kategorije poremećaja raspoloženja, kategorije neurotskih sa stresom povezanih i somatoformnih poremećaja i nekoliko kategorija u kojima se nalaze paranoidni poremećaji (vidi tabelu 1).

Tabela 1. Dijagnoze depresivnih i anksioznih poremećaja pacijenata u uzorku

\begin{tabular}{ll}
\hline Depresivni poremećaji & Paranoidni poremećaji \\
\hline $\begin{array}{l}\text { depresivna epizoda (F32) } \\
\text { rekurentni depresivni poremećaj (F33) }\end{array}$ & $\begin{array}{l}\text { Paranoidna shizofrenija (F20) } \\
\text { Perzistentni poremećaj sa sumanutošću } \\
\text { (F22) } \\
\text { perzistentni poremećaj raspoloženja (F34) } \\
\text { Drugi psihotični por. sa sumanutošću } \\
\text { (F23.3) } \\
\text { kratkotrajna depresivna reakcija }\end{array}$ \\
$\begin{array}{l}\text { N43.2.20) } \\
\text { produžena depresivna reakcija (F43.2.21). }\end{array}$ & Paranoidni poremećaj ličnosti.(F60.0) \\
\hline
\end{tabular}

Grupu subjekata bez psihopatoloških poremećaja čini uzorak od 30 ispitanika koji je sa drugim navedenim grupama u celini, približno ujednačen po starosnoj dobi, stepenu obrazovanja i zastupljenosti polova. Ispitanici iz ove grupe na instrumentima koji su se koristili za razvrstavanje u grupe nisu pokazali znake psihopatoloških poremećaja.

Pacijenti su odabirani za uzorak na osnovu standardizovanog intervjua i profila na MMPI, da bi oni sa odgovarajućom kliničkom slikom bili procenjivani baterijom instrumenata na klinikama u Novom Sadu, Subotici, Somboru, Novom Kneževcu i Vršcu. 


\section{Instrumenti}

Upitnik atribucija zasnovan na ASQ (Attribution Style Questionaire) (Seligman et al., 1979) je konstruisan radi merenja načina atribuiranja kao trajnog obeležja kognitivnog funkcionisanja osobe, odnosno radi provere hipoteza Selidžmenovog reformulisanog Modela naučene bespomoćnosti (Abramson et al., 1978).

Od ispitanika se traži da procenjuju uzroke hipotetskih situacija (6 pozitivnih i 6 negativnih; 6 situacija se tiče postignuća a 6 je afilijativnih). Ispitanik pretpostavlja uzrok tih situacija, i označava na sedmostepenoj Likertovoj skali koliko su uzroci tih situacija unutrašnji ili spoljašnji, koliko su trajni, koliko opšti i koliko su situacije važne za osobu.

Unutrašnja konzistentnost pojedinih dimenzija, izražena Kronbah-alfa koeficijentom, kretala se između 0,44 i 0,69 u istraživanju Kora i Greja (Corr \& Gray, 1996).

Test-retest pouzdanost za period od pet nedelja iznosila je, na osnovu istog istraživanja, između 0,57 i 0,70.

U ovom radu korišćena je prevedena i prilagođena verzija upitnika, u kojoj je sedmostepena Likertova skala zamenjena petostepenom, a tekst nekih situacija je izmenjen tako da bude pristupačniji starijoj i manje školovanoj populaciji. Ova verzija testa ispitana je na uzorku od 300 studenata (Avramovski, 2002 prema Novović, 2004b), kao i na uzorku od 120 anksioznih, depresivnih i anksiozno-depresivnih pacijenata (Novović, 2004). Generalno gledano, manju od dovoljne unutrašnje konzistentnosti pokazuje samo dimenzija stabilnosti i to samo na studentima (tabela 2).

Tabela 2. Pouzdanost atribucionih dimenzija upitnika zasnovanog na ASQ na uzorcima studenata $i$ pacijenata

\begin{tabular}{ll}
\hline & Kronbah-alfa koeficijenti \\
\hline atribucione dimenzije & Studenti Pacijenti \\
\hline internalnost & .71 .73 \\
stabilnost & .51 .66 \\
globalnost & .73 .73 \\
važnost & .84 .77 \\
\hline
\end{tabular}




\section{Rezultati}

\section{Kontrola relevantnih varijabli}

Prosečna starost depresivnih pacijenata je 45,13, paranoidnih 45,56, a kontrolne grupe 43,36 . Grupe se ne razlikuju značajno po starosti $(F(2,115)=0,34 ; p=0,70)$.

U grupama je neujednačena polna struktura: u grupi depresivnih pacijenata muškaraca ima $28 \%$, u grupi paranoidnih $77 \%$, a u kontrolnoj nekliničkoj grupi 50\%. Dvosmerna analiza varijanse sa polom i grupom kao faktorima, a dimenzijama atribuiranja za različite tipove situacija kao zavisnim varijablama (tabela 3), ukazuje da značajan efekat ostvaruje samo grupa, odnosno vrsta ili prisustvo poremećaja. Pol niti pojedinačno niti u interakciji sa faktorom grupa, ne proizvodi značajan efekat u odnosu na zavisne varijable istraživanja. Otuda su dalje analize rađene nezavisno od pola.

Tabela 3. Dvofaktorska analiza varijanse sa faktorima pol i grupa, i dimenzijama atribuiranja kao zavisnim varijablama

\begin{tabular}{|c|c|c|c|c|c|c|}
\hline \multicolumn{7}{|c|}{ Multivarijatni test značajnosti } \\
\hline & Test & vrednost & $F$ & efekat & greška & $p$ \\
\hline Intercept & $\begin{array}{l}\text { Vilksova } \\
\text { lambda }\end{array}$ & .02 & 392.38 & 12 & 101 & .00 \\
\hline$P O L$ & $\begin{array}{l}\text { Vilksova } \\
\text { lambda }\end{array}$ & .93 & .59 & 12 & 101 & .84 \\
\hline GRUPA & $\begin{array}{l}\text { Vilksova } \\
\text { lambda }\end{array}$ & .65 & 2.06 & 24 & 202 & .00 \\
\hline$P O L * G R U P A$ & $\begin{array}{l}\text { Vilksova } \\
\text { lambda }\end{array}$ & .81 & .92 & 24 & 202 & .57 \\
\hline
\end{tabular}

\section{Provera osnovnih hipoteza istraživanja}

U tabeli 4 date su aritmetičke sredine atribucionih dimenzija za pozitivne i negativne situacije kao i za situacije postignuća i socijalnih relacija. 
Tabela 4. Aritmetičke sredine dimenzija atribuiranja u pozitivnim i negativnim situacijama postignuća i socijalnih relacija

\begin{tabular}{llcccccc}
\hline tip situacije & & \multicolumn{3}{c}{ postignuće } & \multicolumn{3}{c}{ socijalne situacije } \\
\hline & dimenzije* & depres. & paran. & kontr. & depres. & paran. & kontr. \\
\hline pozitivne & internalnost & 2.97 & 3.38 & 3.49 & 2.87 & 3.11 & 3.16 \\
& stabilnost & 3.10 & 3.43 & 3.54 & 3.02 & 3.47 & 3.48 \\
& globalnost & 3.41 & 3.74 & 3.21 & 2.98 & 3.33 & 3.29 \\
& važnost & 3.68 & 4.03 & 3.91 & 3.64 & 4.10 & 3.85 \\
\hline \multirow{2}{*}{ negativne } & internalnost & 3.09 & 2.43 & 3.12 & 2.49 & 2.49 & 2.71 \\
& stabilnost & 2.99 & 2.92 & 2.92 & 2.69 & 2.80 & 2.59 \\
& globalnost & 3.18 & 3.46 & 2.67 & 2.58 & 3.23 & 2.64 \\
& važnost & 4.29 & 4.12 & 4.22 & 3.77 & 3.97 & 3.96 \\
\hline
\end{tabular}

*Veći rezultat na dimenziji internalnosti znači veću internalnost uzroka, na stabilnosti veću stabilnost, a na globalnosti veću globalnost.

Razlika između depresivnih, paranoidnih i normalnih ispitanika po dimenzijama atribuiranja pozitivnih situacija koje se tiču postignuća proveravana je multivarijatnom analizom kovarijanse. Nezavisna varijabla je pripadnost grupi pacijenata ili kontrolnoj grupi, zavisne varijable su atribucione dimenzije: internalnost, stabilnost i globalnost, a kovarijat je važnost situacija. Na osnovu multivarijatnih testova značajnosti saznajemo da kovarijat - važnost značajno predviđa rezultate atribuiranja pozitivnih događaja koji se tiču postignuća $(F(3,112)=3,02 ; p<0,05)$. Bez obzira na važnost situacija, pripadnost grupi i dalje ostvaruje značajan efekat takođe $(\mathrm{F}(6.224)=2,78 ; \mathrm{p}<0,05)$.

Tabela 5. Jednosmerne ANOVA-e za pozitivne situacije postignuća

\begin{tabular}{llrrrrrrr}
\hline & & \multicolumn{3}{c}{ internalnost } & \multicolumn{2}{c}{ stabilnost } & \multicolumn{2}{c}{ globalnost } \\
\hline & stepeni & slobode & $\mathrm{F}$ & $\mathrm{p}$ & $\mathrm{F}$ & $\mathrm{p}$ & $\mathrm{F}$ & $\mathrm{p}$ \\
\hline Isečak & 1 & 26.57 & .00 & 16.14 & .00 & 20.34 & .00 \\
VAŽNOST & 1 & 1.70 & .19 & 4.53 & .04 & 7.67 & .01 \\
GRUPE & 2 & 3.37 & .04 & 1.64 & .20 & 2.56 & .08 \\
greška & 114 & & & & & & \\
ukupno & 117 & & & & & & & \\
\hline
\end{tabular}

$\mathrm{Na}$ osnovu jednosmernih ANOVA (tabela 5) saznajemo da se grupe razlikuju jedino po internalnosti atribucija. Depresivni pacijenti se u objašnjavanju pozitivnih situacija postignuća značajno više (Šefeov test kompariranja: $p<0,05$ ) služe atribucijama koje se tiču spoljašnjih okolnosti, od kontrolne grupe (vidi tabelu 4). Paranoidni pacijenti se ne razlikuju značajno od depresivnih i normalnih, mada je njihov prosečan skor bliži onom kod kontrolne grupe, tj. paranoidni sli- 
čno nepatološkim subjektima teže da u većoj meri sebi pripišu odgovornost za pozitivne situacije postignuća (tabela 4 ).

Druga MANCOVA je primenjena radi testiranja razlika između depresivnih, paranoidnih i normalnih ispitanika po dimenzijama atribuiranja koje se tiču pozitivnih socijalnih situacija. Nezavisna, zavisne varijable i kovarijat su isti s tim što se rezultati odnose na pozitivne socijalne situacije.

Multivarijatni testovi značajnosti ne ukazuju na značajan efekat grupe u odnosu na atribuiranje pozitivnih socijalnih situacija $(F(6,224)=1,64 ; p>0,10)$. Važnost situacije u značajnoj meri predviđa skorove na dimenzijama atribuiranja $(\mathrm{F}(3,112)=7,33 ; \mathrm{p}<0,01)$.

Tabela 6. Jednosmerne ANOVA-e za pozitivne socijalne situacije

\begin{tabular}{llrrrrrr}
\hline & \multicolumn{2}{c}{ internalnost } & \multicolumn{2}{c}{ stabilnost } & \multicolumn{2}{c}{ globalnost } \\
\hline & stepeni & \multicolumn{1}{c}{ F } & $\mathrm{p}$ & $\mathrm{F}$ & $\mathrm{p}$ & $\mathrm{F}$ & $\mathrm{p}$ \\
\hline slobode & $\mathrm{F}$ & 17.44 & .00 & 47.33 & .00 & 5.96 & .02 \\
Intercept & 1 & 4.78 & .03 & 1.20 & .16 & 18.93 & .00 \\
Važnost & 1 & .76 & .47 & 4.94 & .01 & .67 & .51 \\
Grupe & 2 & & & & & & \\
Trror & 114 & & & & & & \\
\hline
\end{tabular}

Univarijatni testovi (tabela 6) ukazuju na to da efekat grupe za ceo model nije značajan, ipak univarijatni test ukazuje na visoko značajnu razliku između grupa po stabilnosti. Nakon post hoc kompariranja Šefeovim testom saznaje se da se po stabilnosti atribuiranja pozitivnih socijalnih događaja razlikuje depresivna grupa od kontrolne $(p<0,05)$ i od paranoidnih pacijenata $(p<0,05)$. Depresivni pacijenti objašnjavaju pozitivne socijalne događaje uzrocima kratkog dejstva (manje stabilnim) u odnosu na druge dve grupe (tabela 4).

Sledeća MANCOVA testira razlika između grupa depresivnih, paranoidnih i normalnih ispitanika po dimenzijama atribuiranja negativnih situacija koje se tiču postignuća.U atribuiranju negativnih situacija u vezi postignuća, kako multivarijatni testovi značajnosti sugerišu, efekat grupe je značajan $(F(6,224)=5,64$; $\mathrm{p}<0,001)$, dok je efekat važnosti manji, ali takođe značajan $(\mathrm{F}(3,112)=3,61$; $\mathrm{p}<0,05)$. 
Tabela 7. Jednosmerne ANOVA-e za negativne situacije postignuća

\begin{tabular}{llccccccc}
\hline & & \multicolumn{2}{c}{ internalnost } & \multicolumn{2}{c}{ stabilnost } & \multicolumn{2}{c}{ globalnost } \\
& $\begin{array}{l}\text { stepeni } \\
\text { slobode }\end{array}$ & $\mathbf{F}$ & $\mathbf{p}$ & $\mathbf{F}$ & $\mathbf{p}$ & $\mathbf{F}$ & $\mathbf{p}$ \\
\hline Intercept & 1 & 21.54 & .00 & 46.92 & .00 & 9.93 & .00 \\
Važnost & 1 & 2.38 & .13 & .06 & .80 & 7.73 & .01 \\
Grupe & 2 & 7.22 & .00 & .10 & .90 & 5.83 & .00 \\
Error & 114 & & & & & & & \\
Total & 117 & & & & & & & \\
\hline
\end{tabular}

Na osnovu jednosmernih ANOVA (tabela 7) vidimo da se grupe razlikuju po internalnosti i globalnosti atribuiranja negativnih situacija postignuća (neuspeha). Šefeovim testom kompariranja saznaje se da se paranoidni pacijenti značajno razlikuju i od depresivnih $(\mathrm{p}<0,001)$, a marginalno i od kontrolne grupe $(\mathrm{p}<0,06)$ tako što $u$ većoj meri spoljašnjim atribucijama objašnjavaju negativne događaje u vezi postignuća (tabela 4).

Po globalnosti atribuiranja depresivni pacijenti se marginalno razlikuju od kontrolne grupe $(p=0,05)$, a visoko značajno paranoidni pacijenti od kontrolne grupe $(p<0,001)$. Atribucije paranoidnih su u najvećoj meri globalne, objašnjavaju širok spektar situacija, a takve su u nešto manjem stepenu i atribucije depresivnih, dok se kontrolna grupa služi pretežno specifičnim atribucijama da bi objasnila neuspehe u vezi sa situacijama postignuća (tabela 4).

Razlika između grupa depresivnih, paranoidnih i normalnih ispitanika po varijablama ASQ koje se tiču negativnih socijalnih situacija, ponovo je testirana metodom MANCOVA. Multivarijatni testovi značajnosti ukazuju na značajan efekat i kovarijata $(F(3,112)=5,68 ; p<0,001)$ i grupa $(F(6,224)=2,40 ; p<0,05)$. Efekat kovarijata je značajniji, sugerišući da je pri određivanju uzroka negativnih socijalnih situacija važnost tih situacija značajan činilac skorova na dimenzijama atribuiranja. Ipak, kada se subjekti ujednače po tome koliko su im ove situacije važne, grupe se i dalje razlikuju po atribuiranju.

Tabela 8. Jednosmerne ANOVA-e za negativne socijalne situacije

\begin{tabular}{llrrrrrr}
\hline & \multicolumn{3}{c}{ internalnost } & \multicolumn{2}{c}{ stabilnost } & \multicolumn{2}{c}{ globalnost } \\
\cline { 2 - 8 } & $\begin{array}{l}\text { Stepeni } \\
\text { slobode }\end{array}$ & $\mathbf{F}$ & $\mathbf{p}$ & \multicolumn{1}{c}{$\mathbf{F}$} & $\mathbf{p}$ & \multicolumn{1}{c}{$\mathbf{F}$} & $\mathbf{p}$ \\
\hline isečak & 1 & 26.88 & .00 & 16.22 & .00 & 2.25 & .14 \\
VAŽNOST & 1 & .00 & .96 & 1.30 & .26 & 15.61 & .00 \\
GRUPA & 2 & .70 & .50 & .41 & .67 & 5.20 & .01 \\
greška & 114 & & & & & & \\
Ukupno & 117 & & & & & & \\
\hline
\end{tabular}


Jednosmerne analize varijansi (tabela 6) pokazuju da je u pogledu negativnih socijalnih situacija pripadnost patološkim, odnosno, nepatološkoj grupi, od uticaja samo na globalnost atribuiranja. Na osnovu Šefeovog post hoc kompariranja nađeno je da paranoidni pacijenti pridaju opštije efekte uzročnicima negativnih socijalnih situacija, od depresivnih pacijenata $(\mathrm{p}<0,01)$, a marginalno značajno i od kontrolne grupe $(\mathrm{p}=0,05)$

\section{Diskusija}

\section{Pozitivne situacije postignuća}

Procena „važnosti situacije“, varijabla koja odražava procenu ispitanika o tome koliko bi hipotetska situacija za njega zaista bila važna, značajno predviđa stabilnost i globalnost atribucija za pozitivne situacije postignuća. Što veću važnost ispitanik pridaje hipotetskom uspehu, to mu više pripisuje stabilne i globalne uzroke. ${ }^{2}$ Ovo važi za sve tri grupe gledano zajedno. Mada ne predstavlja atribucionu dimenziju, jer se ne tiče uzroka, već same situacije, važnost situacije globalno gledano doprinosi samoosnažujućoj iluziji. Ovo verovatno najviše važi za paranoidne pacijente i kontrolnu grupu koji u većoj meri ovu vrstu pozitivnih situacija atribuiraju internalno.

Ovakva veza procene važnosti situacije i dimenzija stabilnosti i globalnosti pri atribuiranju pozitivnih situacija postignuća može biti shvaćena kao potvrda Bentalove pretpostavke (Bentall, 1994) da samopotvrđujuće atribuciono iskrivljenje ima funkciju očuvanja samopoštovanja. Za kognitivne procese koji imaju zaštitnu (Bentall, 1994; Blackwood et al., 2001) i funkciju očuvanja nepromenljivosti kognitivne šeme (Beck, 1976) bi se moglo i očekivati da se u većoj meri manifestuju baš u onim situacijama koje osoba procenjuje kao važne - dakle, one u vezi sa kojima ona može naći potvrdu ili osporavanje bazičnih sadržaja kognitivne šeme, slike o sebi, samopoštovanja. Naravno, moguća su i druga tumačenja uzročno posledičnog niza. Procena situacija kao važnijih može biti posledica generalizacije uspeha kroz globalnije i stabilnije atribucije, sa istim ciljem osnaživanja samopoštovanja. Treća mogućnost je da i generalizacija uzroka uspeha i podizanje značaja ovim situacijama mogu biti posledice trećeg faktora, kompleksnog, zaštitnog kognitivnog mehanizma koji usklađuje realnost sa self-šemama na način da osobi obezbedi održanje samopoštovanja.

\footnotetext{
${ }^{2}$ Sve značajne korelacije između važnosti situacije i atribucionih dimenzija su pozitivne. Ovo je provereno dodatnim korelacionim analizama, ali je izostavljeno iz prikaza jer prevazilazi obim ovog rada
} 
Paranoidni pacijenti su prema atribuiranju pozitivnih situacija postignuća slični ispitanicima bez poremećaja, kao što pretpostavlja Bentalova Atribuciona teorija (Blackwood et al., 2001), odnosno, oni pokazuju samopotvrđujuće atribuciono iskrivljenje $\mathrm{e}^{3}$ - pozitivno postignuće pripisuju u većoj meri sebi.

Depresivni pacijenti u većoj meri od ostalih ispitanika pripisuju uzroke pozitivnih postignuća drugim ljudima ili okolnostima, što je već robustan rezultat atribucionih istraživanja depresivnih pacijenata (pregled u Sweeney et al., 1986). Međutim, veća specifičnost i nestabilnost pripisanih uzroka pozitivnim situacijama, što su takođe odlike pesimističkog atribuiranja, nije potvrđena kod depresivnih pacijenata u našim rezultatima. Ovaj «krnji» depresivni atribucioni stil za situacije uspeha, gde se sopstveni udeo u stvaranju ovih situacija u većoj meri negira, ali se zato stabilnost, globalnost i važnost ne povećavaju kako bi samoporažavanje bilo što veće, otvara pitanje autentičnosti negiranja svoje zasluge za uspeh kod depresivnih pacijenata. Izgleda kao da naši pacijenti delom atribuiraju $\mathrm{u}$ «korist svoje štete», a delom i štite sebe od ovakvih zaključaka, ne povećavajući bar njihove implikacije. Da li je negiranje odgovornosti za uspeh deo «lažne skromnosti», odnosno hrišćanskih vrednosti u koje ne spada preterano hvalisanje, dok se normalna potreba za pozitivnim stimulusima prepoznaje po stepenu generalizovanja uzroka ovih situacija, koja se ne razlikuje od one kod nekliničke populacije $\mathrm{i}$ drugih tipova pacijenata? Na razlike $\mathrm{u}$ «javnom» $\mathrm{i}$ «privatnom» atribuiranju, kao i značaj kulturnih i religijskih uticaja na atribuiranje ukazao je Peterson (Peterson, 1991, prema Novović, 2004), a naši rezultati bi se mogli uklopiti u ove hipoteze.

\section{Pozitivne socijalne situacije}

Sličan sklop rezultata dobijen je i za atribuiranje pozitivnih socijalnih situacija. Opažanje situacije kao važnije povezano je sa internalnijim i globalnijim atribuiranjem socijalnog uspeha. I ovaj rezultat može odražavati generalnu potrebu ljudi da «pojačavaju efekat» pozitivnih situacija tako što će se povećati njihov značaj, posebno onih uspešnih situacija za koje se smatraju odgovornima.

\footnotetext{
${ }^{3} \mathrm{O}$ tome da se zaista radi o pozitivnoj iluziji govore sledeći rezultati: distribucija odgovora na dimenziji internalnosti za pozitivne situacije postignuća, u grupi paranoidnih pacijenata značajno odstupa od teorijske sa $\mathrm{AS}=3, \mathrm{SD}=0,44$ u pravcu veće internalnosti (Kolmogorov-Smirnov d $=$ 0,$81 ; \mathrm{p}<0,01$ ), a takođe i u kontrolnoj grupi (Kolmogorov-Smirnov $\mathrm{d}=0,81$; $\mathrm{p}<0,01)$.
} 
Kod pozitivnih socijalnih situacija se stabilnost atribuiranja pokazuje značajnom u odvajanju depresivnih pacijenata od ostalih grupa ukazujući na tendenciju depresivnih da socijalnom uspehu kompletnije devalviraju vrednost $\mathrm{u}$ odnosu na ostale ispitanike. Depresivni pacijenti se, doduše ne značajno, smatraju i manje zaslužnim za socijalni uspeh, ali značajno umanjuju implikacije ovih hipotetskih situacija, smatrajući ih značajno manje trajnim od ostalih grupa (i manje globalnim, ali ne na nivou statističke značajnosti). Međutim, ako pogledamo prosečne vrednosti atribuiranja ovih situacija kod depresivnih pacijenata (tabela 7) možemo primetiti da oni u stvari pokazuju nepristrasno atribuiranje na dimenzijama tj. «depresivni realizam», jer se njihove prosečne vrednosti kreću oko teorijskog proseka (3), za razliku od paranoidnih i kontrolne grupe koji u ovim situacijama ponovo atribuiraju pristrasno u svoju korist. Interesantno je da smo rezultat koji govori u pravcu realističnog atribuiranja depresivnih dobili na kliničkom uzorku, što nije slučaj u većini drugih istraživanja, koji su ovaj fenomen uglavnom potvrđivali na nepatološkim uzorcima - studentima (Haaga \& Beck, 1995). U slučaju socijalnih situacija doprinos važnosti situacija se pokazao značajnijim od uticaja patologije, što govori i o tome da je važnost i ovde varijabla koja moderira efekat psihopatologije na način atribuiranja.

\section{Negativne situacije postignuća}

Pri atribuiranju negativnih situacija postignuća, paranoidni pacijenti ispoljavaju izrazito atribuciono iskrivljenje u samozaštitnom smeru. Dakle, uzroke neuspeha više pripisuju drugima, ali te uzroke vide kao nešto što se odnosi na većinu životnih okolnosti: za neuspehe su u svakom slučaju krivi drugi, i to zbog toga što su generalno zlobni, neprijatni i sl., te se slične neprilike mogu očekivati u širem rasponu situacija. Ovo i rađa doživljaj ugroženosti što je, prema Bentalu, cena koju paranoici plaćaju da bi održali svoje samopoštovanje. Rezultati istraživanja kognitivnih procesa kod paranoidnih pacijenata na domaćem uzorku (CvejićStarčević, 2008) potvrđuju povezanost samozaštićujućeg atribucionog iskrivljenja i self-koncepta: iako se generalni self-koncept kod paranoidnih pacijenata pokazao negativnim u meri koliko i kod depresivnih, ove grupe su se značajno razlikovale prema onim aspektima samoprocene koji se odnose na sposobnost $\mathrm{i}$ inteligenciju. Normalni nivoi samoprocene prema tim grupama osobina kod paranoidnih ispitanika mogu ukazivati na efekat samozaštićujućeg atribucionog iskrivljenja, kao što predlaže Bental. 


\section{Negativne socijalne situacije}

Paranoidni ispitanici uzroke socijalnih negativnih situacija vide kao više globalne, odnosno kao nešto što utiče na više situacija u njihovom životu, u značajno većoj meri nego ostale grupe ispitanika. Pripisivanje neprijateljstva i zlonamernosti drugima je čest sadržaj paranoidnih sumanutosti koje, prema Bentalu, imaju samozaštitne efekte. U socijalnim negativnim situacijama, kao što je kritikovanje od strane drugih, ovakvo atribuiranje mora biti ekstremnije i rigidno i lako dostupno u svakom momentu, da bi ostvarilo svoju funkciju, a izraženija globalnost može biti odraz ovih karakteristika. Ovi rezultati se mogu posmatrati i u svetlu nalaza istraživanja koji pokazuju da osobe sa paranoidnim poremećajima pokazuju otežano prisećanje konkretnih autobiografskih iskustava (Kaney et al., 1999): u odnosu na ispitanike bez poremećaja, u značajno većoj meri se prisećaju opštih, naročito kategoričnih iskustava - njihova dostupna sećanja su u većoj meri uopštena.

Paranoidni se više razlikuju od ostalih grupa po eksternalizaciji neuspeha u situacijama postignuća, nego u socijalnim situacijama, gde su grupe ujednačene po internalnosti atribuiranja socijalnog neuspeha. Pri tome se prosečne vrednosti socijalnih atribucija sve tri grupe nalaze ispod teorijske sredine od 3. Ovo govori da se pri atribuiranju socijalnog neuspeha sve tri grupe u većoj meri služe eksternalizacijom, odnosno da je tendencija ka negiranju odgovornosti u negativnim socijalnim situacijama donekle univerzalna, nezavisna od patologije (bar kad je reč o depresivnim i paranoidnim poremećajima). Moguće objašnjenje je da su socijalne situacije manje podložne objektivnom procenjivanju, nasuprot situacijama postignuća koje imaju čvršće i jasnije kriterijume i uspeha a i odgovornosti, te se zato iskrivljavanjem realnosti u socijalnim situacijama služe sve grupe, a u situacijama postignuća pristrasnost se pojavljuje samo kod ispitanika čiji je kontakt sa realitetom najugroženiji - kod paranoidnih.

Različito dejstvo poremećaja na atribuiranje situacija postignuća i socijalnih relacija, ukazuje na opravdanost upotrebe ove varijable u istraživanjima depresivnih i paranoidnih pacijenata. Korisno bi bilo proveriti efekat na atribuiranje socijalnih i situacija postignuća, osobina sociotropnih i autonomnih ličnosti o kojima govori Beck (Beck, Robbins, Taylor \& Baker, 2001) jer bi one mogle biti značajan medijator u relaciji tip situacije - atribuiranje.

\section{Zaključak}

Rezultati ovog istraživanja potvrđuju pretpostavku Atribucione teorije sumanutosti (Bental, 1994), da paranoidni pacijenti pokazuju prenaglašeno samopotvr- 
đujuće atribuciono iskrivljenje, po čemu se razlikuju od depresivnih pacijenata. U odnosu na depresivne, paranoidni pacijenti pozitivne situacije objašnjavaju sopstvenim atributima, a negativne događaje objašnjavaju u većoj meri spoljašnjim okolnostima. Ova pristrasnost se, međutim, ispoljava samo u situacijama vezanim za postignuće, suprotno našem očekivanju. Pretpostavka o sklonosti paranoidnih pacijenata da događajima pripisuju stabilne i globalne uzroke za negativne situacije potvrđena je, i to za dimenziju globalnosti. Paranoici negativne situacije u većoj meri objašnjavaju uzrocima koji imaju širi opseg delovanja.

Važnost situacija koje se atribuiraju je povezana sa atribucionim stilom, tako da je procenu situacija na skali važnosti nužno držati pod kontrolom jer se različita važnost različitih tipova situacija odražava na atribuiranje.

Vrsta situacije (situacije povezane sa postignućem, u poređenju sa socijalnim situacijama) su takođe značajno povezane sa atribucionim stilom, sugerišući da se više relevantnih informacija može dobiti uključivanjem i ove varijable ASQ-a $\mathrm{u}$ analizu.

Najznačajniji rezultat ovog istraživanja, koji je, koliko je autorima poznato, i nov $\mathrm{u}$ atribucionim istraživanjima paranoidnih pacijenata, je da je paranoidna atribuciona pristrasnost vezana za situacije postignuća, a ne toliko socijalne. Ovo ukazuje na to da je sa ovom vrstom pacijenata nužno raditi na onom delu selfkoncepta koji se tiče postignuća.

Nalaženje drugačijih načina za potvrđivanje onih aspekata self-koncepata koji su paranoidnim osobama posebno važni (a koji se odnose na sposobnost), npr. preispitivanje, nalaženje dokaza iz realnosti i argumentovano i kritičko potvrđivanje, može ova atribuciona iskrivljenja učiniti nepotrebnim i tako doprineti njihovoj normalizaciji.

\section{Reference}

Abela, J. R. Z., Brozina, K., \& Seligman, M. E. P. (2004). A test of integration of the activation hypothesis and the diathesis-stress component of the hopelessness theory of depression. British Journal of Clinical Psychology, 43, 111-128.

Abramson, L.Y., Seligman, M. E. P., \& Teasdale, J. (1978). Learned helplessness in humans: Critique and reformulation. Journal of Abnormal Psychology, 87, 49-74.

Alloy, L. B., \& Clements, C. M. (1998). Hopelessness theory of depression: Tests of the symptom component. Cognitive Therapy and Research, 22, $303-335$. 
Avramovski, T. (2002). Veza između atribucionog stila, pola i nekih aspekata samopoimanja. Neobjavljeni diplomski rad. Filozofski fakultet, Univerzitet u Novom Sadu, Novi Sad.

Beck, A. T., \& Rector, N. A. (2002). Delusions: A cognitive perspective. Journal of Cognitive Psychotherapy, 16, 455-468.

Beck, A. T. (1976). Cognitive therapy and emotional disorders. New York: New American Library.

Beck, R., Robbins, M., Taylor, C., \& Baker, L. (2001). An examination of sociotropy and excessive reassurance seeking in the prediction of depression. Journal of Psychopathology and Behavioral Assessment, 23, $101-105$.

Bentall, R. P., Corcoran, R., Howard. R., Blackwood, N., \& Kinderman, P. (2001). Persecutory delusions: a review and theoretical integration. Clinical Psychology Review, 21, 1143-92.

Bentall, R. P., \& Kaney, S. (1996). Abnormalities of self representation and persecutory delusions: a test of a cognitive model of paranoia. Psychology Medicine, 26, 1231-1237.

Bentall, R. P. (1994). Cognitive biases and abnormal beliefs: towards a model of persecutory delusions. In David A. S., Cutting J. (Eds.) The neuropsychology of schizophrenia (pp. 337-360). Hove, UK: Lawrence Erlbaum Associates.

Biro, M. (1995). Dijagnostička procena ličnosti. Novi Sad: Futura publikacije i Filzofski Fakultet.

Blackwood, N. J., Howard R. J., Bentall, R. P., \& Murray, R. M. (2001). Cognitive neuropsychiatric models of persecutory delusions. American Journal of Psychiatry, 158, 527-539.

Candido, C. L., \& Romney, D. M. (1990). Attributional style in paranoid vs depressed patients. British Journal of Medical Psychology, 63, 355-363.

Chadwick, P. D. J., Trower, P., Juusti-Butler, T. M., \& Maguire, N. (2005). Phenomenological evidence for two types of paranoia. Psychopathology, 38, 327-333.

Corr, P. J., \& Gray, J. A. (1996). Structure and validity of the attributional style questionnaire: A cross-sample comparison. Journal of Psychology, 130, 645-657.

Cvejić-Starčević, N. (2008). Provera hipoteze o specifičnosti kognitivnih sadržaja $i$ atribuiranja kod tri grupe psihopatoloških poremećaja. Nepublikovani magistarski rad. Filozofski Fakultet, Univerzitet u Novom Sadu, Novi Sad. 
Garety, P. A., \& Freeman, D. (1999). Cognitive approaches to delusions: a critical review of theories and evidence. British Journal of Clincal Psychology, 38, 113-154.

Fiske, S. T., \& Taylor, S. E. (1991). Social Cognition. New York: McGraw-Hill. Freeman, D., Garety, P., Fowler, D., Kuipers, E., Dunn, G., Bebbington, P., \& Hadley, C. (1998). The London-East Anglia randomized controlled trial of cognitive-behaviour therapy for psychosis, IV: self-esteem and persecutory delusions. British Journal of Clinical Psychology, 37, 415-430.

Haaga, D. A., \& Beck, A. T. (1995). Perspectives on depressive realism: implications for cognitive theory of depression. Behavioral Research and Therapy, 33, 41-48.

Humphreys, L., \& Barrowclouqh, C. (2006). Attributional style, defensive functioning and persecutory delusions: symptom-specific or general coping strategy?. Journal of Clinical Psychology, 45, 231-46.

Kaney, S., Bowen-Jones, K., \& Bentall, R. P. (1999). Persecutory delusions and autobiographical memory. Journal of Clinical Psychology, 38, 97- 102.

Kaney, S., \& Bentall, R. P. (1989). Persecutory delusions and attributional style. Journal of Medical Psychology, 62, 191-8.

Kinderman, P., \& Bentall, R.P. (1997). Causal attributions in paranoia and depression: internal, personal and situational attributions for negative events. Journal of Abnormal Psychology, 106, 103-107.

Lyon, H. M., Kaney, S., \& Bentall R. P. (1994). The defensive function of persecutory delusions: evidence from attribution tasks. British Journal of Psychiatry, 164, 637-46.

Mineka, S., Pury, C. L., \& Luten, G. A. (1995). Explanatory style in anxiety and depression. In G. M. Buchanan \& M. E. P. Seligman (Eds.) Explanatory style. Hillsdale, NJ: Lawrence Erlbaum associates.

Novović, Z. (2004b). Diskriminativni značaj kognitivnih, afektivnih i akcidentalnih varijabli u diferenciranju ankzioznih i depresivnih stanja. Nepublikovana doktorska disertacija. Filozofski Fakultet, Univerzitet $\mathrm{u}$ Novom Sadu, Novi Sad.

Seligman, M. E. P. (1975). Helplessness: on depression, development and death. San Francisco: Freeman.

Seligman, M. E. P.(1990). Explanatory style, helplessness, and depression. In C. R. Snyder D. R. Forsyth (Eds.) Handbook of social and clinical psychology: The health perspective (pp 267-282). New York: Pergamon Press. 
Seligman, M. E. P., Abramson, L. Y., Semmel, A., \& von Baeyer, C. (1979). Depressive attributional style. Journal of Abnormal Psychology, 88, 242247.

Svetska zdravstvena organizacija (1992). ICD-10 Klasifikacija mentalnih poremećaja i poremećaja ponašanja: Klinički opisi i dijagnostička uputstva. Beograd: Zavod za izdavanje udžbenika.

Sharp, H. M., Fear, C. F., \& Healy, D. (1997). Attributional style and delusions: an investigation based on delusional content. European Psychiatry, 12, 17.

Sweeney, P. D., Anderson, K. \& Bailey, S. (1986). Attributional style in depression: A Meta-analytic review. Journal of Personality and Social psychology, 50, 974-991. 


\title{
ABSTRACT
}

\section{SPECIFIC CHARACTERISTICS OF ATTRIBUTIONAL STYLE IN PARANOID PATIENS COMPARED TO DEPRESSED PATIENTS AND NON-CLINICAL CONTROLS}

\author{
Nataša Cvejić-Starčević \& Zdenka Novović
}

The hypothesis about the paranoid attributional style was tested by comparing the groups of depressive, paranoid and normal subjects. Patients with depressive $(\mathrm{N}=58)$ and paranoid disorders $(\mathrm{N}=30)$ were compared to normal controls $(\mathrm{N}=30)$. The groups were matched for age. An instrument based on the Attributional Style Questionnaire was used to measure the dimensions of attributional style. The data were subjected to a multivariate analysis of covariance, with groups as an independent variable, the dimensions of attribution as dependent variables, and the importance of situations as a covariate. The results showed that the paranoid patients tended to attribute success to internalizing causes, and to attribute negative situations to externalizing causes to a greater extent than the depressed and control groups. Also, their attributions were more global compared to the other groups. In some situations, the importance of situations was a significant element of attributioning, even more significant than the kind of disorder. In attributing negative achievement situations, the paranoid patients showed the largest attributional bias. All three groups tended to show an attributional bias for negative social situations, suggesting that future attributional research need to control for the situation types. The most important implication of this study is that in treatment of paranoid patients a greater emphases should be placed on self-respect enhancement, as a way of changing their attributional biases.

Key words: attributions, paranoid disorders, depression, cognitive bias 